\title{
Optimized Renovation Strategies of Education Building - a novel BIM/BPM/BEM framework
}

\author{
Ming $\mathrm{Hu}$ \\ ${ }^{1}$ University of Maryland, College Park, United States
}

\begin{abstract}
Educational building in United State account for around $14 \%$ of overall non-residential floor area. $76.61 \%$ of education building are twenty years old or older when the major building systems and equipment reach their service life span, and $38.30 \%$ of buildings are 50 years older or older which is nearly the expected serviceable lifespan of the buildings (CBECS, 2012). The aim of this paper is to propose a novel Building information model (BIM)Building performance model (BPM) - Building environmental model (BEM) framework to identify the most energy efficient and cost effective strategies to renovate the existing education building to achieve the nearly zero energy goal while minimizing the environmental impact. A case building is used to demonstrate the validity of framework, and a set of building performance indicators includes energy performance, environmental impacts, occupant satisfaction are used to evaluate the renovation strategies. This novel framework further demonstrates the interoperability among different digital tools and platform as well. Lastly, the case study results highlight the particular energy profile and retrofit needs of education buildings with detailed analysis and measurement.
\end{abstract}

\section{Introduction}

Educational building in United State account for around $14 \%$ of overall non-residential floor area. $76.61 \%$ of education building are twenty years old or older when the major building systems and equipment reach their service life span, and $38.30 \%$ of buildings are 50 years older or older which is nearly the expected serviceable lifespan of the buildings (CBECS, 2012) (refer to figure 1).

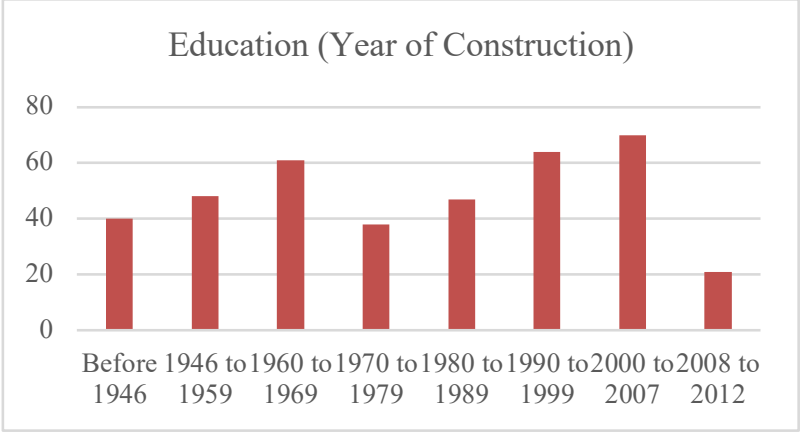

Figure 1 Age of education buildings (created by author based on CBECS 2012 data)
There are some studies focusing on education building energy renovation and retrofit. Ascione et al. (2015) proposed a method to diagnose energy performance aimed at integrated design of energy refurbishment of existing buildings. The research team used the method of combination of heat flow measurement, infrared thermography, energy simulation and situ investigation. Variety renovation strategies have been tested such as reduction of infiltration, replacement of windows and increase of thermal insulation of building façade, the results show it is possible to achieve large amount energy saving with cost and construction constraints. De Angelis et al. (2015) evaluated the energy reduction potential through building envelope renovation and renewable energy production. Their results show the maximum energy reduction of $37.3 \%$ can be achieved by improving thermal properties of envelope together with effective natural ventilation. Niemela et al. (2016) demonstrated the near zero energy building target can be costeffectively achieved in existing education building in Finland, and they also found the energy saving potential of HVAC system is significant compared to the building envelope. Dalla Mora et al. (2017) studied an existing school building located in Italy, and several combinations of retrofit measures been applied to derive the costeffective solutions for renovation. Fonseca et al. (2018) designed a renovation plan for Department of electrical and computer engineering building with the aim to achieve nearly zero energy goal using two primary technologies: LED lighting and photovoltaic panel. Irulegi et al. (2017) studied an education building in Spain and proposed different renovation strategies for the winter and summer time, and proved that the total energy saving potential could be up to $62 \%$. However, the information on the energy consumption of this type of buildings are still limited compared to other commercial and residential buildings (Ascione et al. 2014; Med, 2010; Boarin and Davoli, 2015, Zinzi et al., 2015). And most reports focus on primary and secondary school buildings, which left very limited studies concentrate on higher education buildings.

\section{Case Project}

The general shape of the building is two different size of rectangular that located at latitude of $38^{\circ} 59^{\prime} 3.73 \mathrm{~N}$ and longitude of $76^{\circ} 56^{\prime} 51.57 " \mathrm{~W}$. The 2-storey building occupy a ground floor area of $6517 \mathrm{~m}^{2}\left(70,150 \mathrm{ft}^{2}\right)$, and the total area conditioned area is $4355 \mathrm{~m}^{2}\left(46,877 \mathrm{ft}^{2}\right)$. The main façade is oriented towards the south and north. The 
building is composed of classrooms, auditorium with around 200 seats, offices, library, conference rooms, two computer labs and a gallery space. The building has a large atrium space in the center with skylights and classrooms facing south and north. Majority offices are arranged around shaded courtyard at second floor, so the orientation of offices varies, and most of offices do have a window and views. The original building was constructed in 1972, there were several renovations, and revisions have been done after the initial construction. The gallery lighting system was replaced and upgraded in 1992, and the chiller was replaced in 1997. Major renovations happened in 1998, compute rooms were renovated, as well as the large auditorium space. In 2007, additional librarian offices were added as part of library addition and later in 2009, the visual resource center was also added in the library. As estimated by university estimated, to completely replace the existing building with a new one which meet the modern codes and standard, the total cost (include all soft cost) is $\$ 36,391,731$ (\$518/sqft), to renovate the existing building will cost around $\$ 26,565,950$ (\$379/sqft) (UMD, 2018).

\section{Methodological approach and process}

The research methodology is based on proposed BIMBEP-BEM framework: BIM stands for Building Information Model, BPM represents Building Performance Model, and BEM is Building Environment Model (refer to figure 2).

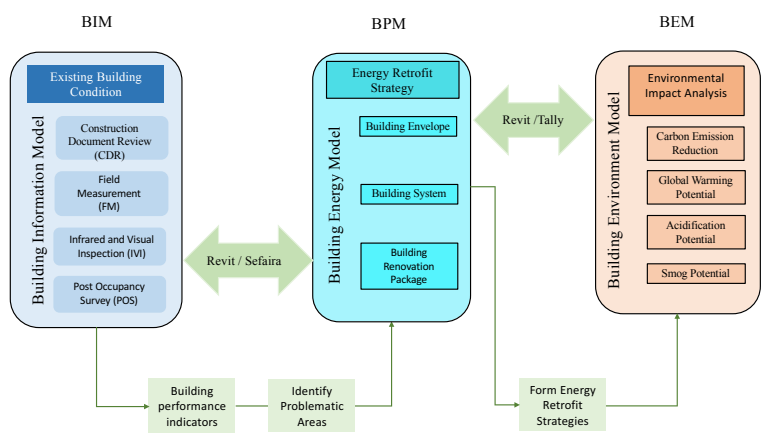

Figure 2. Research framework: BIM-BPM-BEM

Building information model (BIM) is a process involving the generation and management of digital representations of physical and functional characteristics of buildings. BIMs are files can be extracted, exchanged or networked to support decision-making regarding a building or other built asset (Wiki, 2018). BIM also brings the opportunity to try out solutions in advance before building the structure on site: with a constructible model, the design solutions can be prototyped virtually ( $\mathrm{Lu}$ et al., 2014, Abanda et al., 2013). BIM has been recognized as a suitable method for support planning, collaboration and design of new or existing buildings (Gourlis and Kovasic, 2017). More practice-oriented publications often advocate BIM benefits as maximization of efficiency quality and reducing time effort (McGraw Hill, 2009). It is also understood as a digital platform which enables interoperability and data-exhange (Kiviniemi et al., 2008). BPM often time is called as building energy model which the focus on energy performance, the process of BIM to building energy model has been extensively studied in past several years with lots of success (Miller et al., 2014, Zhao et al., 2015, Thomas et al., 2014). However, the linkage between BIM, building energy performance and environment impact has not be fully established. Wong et al (2015) pointed out there is limited research effort for managing environmental performance at the building renovation stage and there is a lack of comprehensive BIM-based environmental sustainability simulation tool. Chong et al. (2017) outlined there is a need for improved interoperability among BIM software and energy simulation tools especially in renovation and refurbishment projects.

In this research project, based on original construction documents and on-site measurement, firstly, a virtual BIM model was constructed and software chosen for this project is Autodesk Revit ${ }^{1}$. Then the information and data from BIM model were transferred to a building performance simulation program called Sefaira. Sefaira is a cloud-based software could simulate building energy performance and visualize daylighting quality in the spaces. It has plug-in tool in Autodesk Revit that could translate building information and data such as location, area, building system, materials, geometry, window configuration and functional use to an online platform. Alternative design options or renovation package could be set up in the cloud, the output such as energy reduction, carbon emission reduction and cost could be compared. It also accounts for occupant behaviour in regression forms. For instance, modeller could create and define different energy model profile based on the set temperature (user preference) and operational schedule. In this research project, multiple BPM models were created in the cloud and results are compared and explained in the following sections. Finally, the material and building system information were extracted from BIM model and translated into a BEM model. The software used for transferring data and run environmental impact analysis is Tally. Tally is the first software that has direct plug-in in Autodesk Revit that allow modeller and designers run a whole building life cycle assessment of the environmental impact from different design solutions. The output from the environmental analysis include acidification potential, eutrophication potential, global warming potential, ozone depletion potential and smog formation potential. The following sections present different parts of the methodology applied in this case project.

\section{Building information model (BIM)}

BIM stage in this research comprise four components: construction document review (CDR), field measurement (FM), infrared and visual inspection (IVI), post

\footnotetext{
1 Autodesk Revit is a BIM software developed by Autodesk, it also 4D capability to track various building life cycle stages.
} 
occupancy survey (POS) and BIM model building. The primary purposes during BIM stage are three: (1) generate an overall assessment of existing building conditions; (2) identify the problematic areas and potential improvement opportunities according to the alignments and discrepancies from CDR, FM, IVI and POS; (3) set up BIM model based on information from IVI, POS, FM and CDR, then prepare for data extraction to BPM and BEM models (refer to figure 3 ).

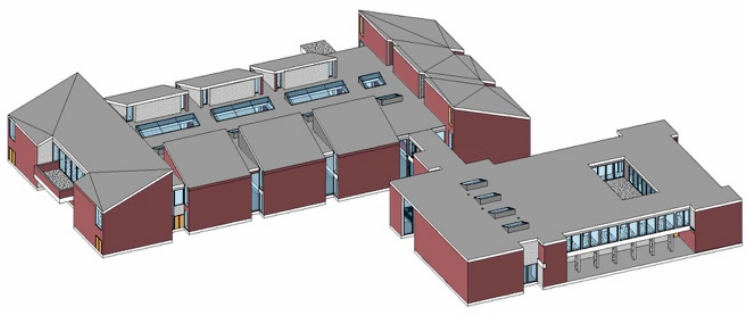

Figure 3 BIM model of Architecture building

\section{Building performance model (BPM)}

In this research project, there is limited amount control of building embodied energy since large portion of it has already spent in the initial construction of existing building. So author focus on existing and future operational energy performance of the building. BPM comprise three steps: (1) identify and simulate building envelope retrofit techniques, (2) identify and simulate building system retrofit techniques, (3) identify and simulate building retrofit package based on results from 1 and 2. The metric used to measure and compare the techniques and packages are: total energy reduction (\%), total $\mathrm{CO} 2$ emission reduction relate to energy $(\%)$, cost saving per year (\%), initial construction cost (low to high) and construction feasibility (low - high). The primary purposes during BPM stage is to create a ranking of the proposed renovation packages from energy saving and cost optimized perspectives. The software used for simulation is Sefaira system ${ }^{2}$. The construction and maintenance cost information are provided by facility management office of University of Maryland.

\section{Building environment model (BEM)}

In stage three, different retrofit packages were investigated and compared to further understand their environmental impact. Five environmental impact indicators selected for this study are global warming potential, ozone depletion potential, acidification potential, eutrophication potential and smog formation potential. The tool used for analysis is Tally. Tally is the only application conducting life cycle assessment that is fully integrated with Autodesk Revit model. It counts the environment impact during the whole building life cycle from raw material extraction to demolition. Tally use

2 Sefaira Architecture is a collaborative, cloud-based software that combines an engaging, easy-to-learn interface with validated industry-standard analysis engines.
Gabi Life cycle inventory (LCI) database, which is one of the leading database used by life cycle analysis practitioners (Kellens et al., 2012; Kounia et al., 2013). The model created in BIM includes all necessary data of building assemblies and systems such as windows, doors, walls, columns and floors, HVAC system, etc, the plugin tool Tally allows researcher to map the BIM objects with Gabi LCI database to run the analysis of environmental impact of different renovation packages. The detailed results and explanation are presented in the following section, section 4: findings.

\section{Energy retrofit techniques-envelope and lighting system}

To tackle the two primary problematics areas, focus of retrofit techniques are given to exterior envelope upgrades and interior partition retrofit first. In existing building, exterior wall and partition walls are either made of CMU block or cast-in place concrete without thermal and acoustic insulation. Renovation techniques identified for building envelope are:

- T1: Substitution of present window with lowemissive units (with U value of $0.25 \mathrm{w} / \mathrm{m}^{2} \mathrm{k}$ )

- T2: Application of additional thermal insulation to the roof slab (R 50)

- T3: Application of additional thermal insulation for the exterior walls a (add additional 3 inch panels of expanded polystryrene insulation, R38)

- T4: Application of additional thermal insulation for the interior walls a (add additional 2 inch panels of expanded polystryrene insulation, R10)

- T5: Replace all existing windows with double glazing window units.

- T6: Reduce air infiltration by using air-tight window (air infiltration rate, $0.3 \mathrm{~L} / \mathrm{s} \cdot \mathrm{m}^{2}, 0.06 \mathrm{cfm} / \mathrm{ft}^{2}$ )

- T7: Replace all existing lights with LED lighting

- T8: Application of Phase change material (PCM) wall board on the inside face of exterior wall

Based on the available achieved records, there were no major upgrades/renovation done to building envelope, therefore, improving exterior wall and roof insulation were considered first as well as improving window energy performance. Roof insulation can be increased to R50 by adding additional panels of expanded polystyrene (Ascione et al., 2015) (thickness $10 \mathrm{inch}$ ). The overall achievable annual saving is around $250,671 \mathrm{Kwh}$, and it implies avoided $\mathrm{CO}_{2}$ equivalent emissions of about $22 \%$ compared to the existing building. The cost of this renovation techniques including demolition and repair the surface of roof is around $\$ 33,230 \sim \$ 64,839$ based on unit cost of $\$ 10.25 / \mathrm{ft}^{2} \sim \$ 20 / \mathrm{ft}^{2}$ (Ojczyk, 2014). In the first year of installation the saving can be realized. The existing building has minimal $\mathrm{R}$ value on exterior wall, adding additional insulation board on the inner face of exterior 
wall could increase the $\mathrm{R}$ value to $\mathrm{R} 38$. The retrofit of exterior wall alone could save energy use around 290,635 $\mathrm{Kwh}$, and $\mathrm{CO}_{2}$ emission reduction around $21 \%$. Insulation could also be applied to the surface of interior wall with insulating plaster which could also provide acoustic insulation. With 2 inch thermal plaster, it potentially add additional R10 insulation [19], which represent great reduction of heat transmittance through the rooms and preventing sound transmission. The total energy saving is around $3 \%$, and $\mathrm{CO}_{2}$ emission reduction around $8 \%$. Another practical envelope retrofit techniques include replace existing glass with low-e glazing, or replace all single-pane glass with double pane glass. The latter result into $19 \% \mathrm{CO}_{2}$ emission reduction and $11 \%$ energy consumption reduction respectively.

Most buildings on campus were built around late 1960s and early $1970 \mathrm{~s}$, and the air infiltration rate varied from $3.0 \times 10^{-4}$ to $3.0 \times 10^{-4} \mathrm{~m}^{3} / \mathrm{s} . \mathrm{m}^{2}(\mathrm{pa})^{0.65}\left(2.1\right.$ to $4.9 \mathrm{cfm} / \mathrm{ft}^{2}$ (in.of water). And 15 to $45 \%$ of over-all air leakage could be attributed to flow through the intake and exhaust system openings (Shaw et al., 1979; Sherman and Chan 2006; Persily, 1998). Based on ANSI/ASHRAE standard 62.1-2016, the minimal requirement for office space, auditorium seating area is $0.06 \mathrm{cfm} / \mathrm{ft}^{2}$, for library is 0.12 $\mathrm{cfm} / \mathrm{ft}^{2}$ (ANSI/ASHRAE 2016). Reduce air infiltration through façade has the most obvious gain in saving energy used for heating, about $27 \%$ reduction. As heating account for $44 \%$ of overall energy consumption, reducing air infiltration by tightening the building envelope could be most efficient technique saving energy, which is equivalent of $\$ 29,643$ saving.

Two other techniques compared are replacing existing T4 and T8 lighting fixtures with LED lights and adding phase change materials in the exterior wall. Lighting count for $9 \%$ of overall energy consumption, installing LED lights could save around $282,375 \mathrm{KWh}, 12 \%$ compared to baseline. Phase change materials(PCM) could be added into the wallboard to increase insulation (Barbero et al., 2014). After comparing the different techniques, overall, $\mathrm{T} 6$ and $\mathrm{T} 8$ generate most energy consumption reduction and $\mathrm{CO} 2$ emission reduction, $\mathrm{T} 4$ follow as the third most effective techniques.

In terms of cost, T6 is most cost effective (saving) in comparison to other techniques, $\mathrm{T} 8$ follow as second (refer to table 3). T2 and T7 are most effective in reducing peak heating load and peak cooling load (refer to figure 9). In terms of initial construction cost, T6 cost the least and T5 has the highest cost, T8 is hard predicate, and the rest techniques share similar per unit cost. When looked at the construction feasibility, $\mathrm{T} 7$ is most practical strategy and T8 is least feasible due the accessibility of phase change materials.

\section{Energy retrofit techniques-building system}

Renovation techniques identified for building system are:

- HVAC1: VAV with rooftop package unit

- HVAC 2: VAV with central plant

- HVAC 3: DOAS System (Package Terminal AC)

- HVAC 4: DOAS System (Split System)
- HVAC 5: DOAS System (Fan Coil Units and Central Plant)

- HVAC 6: DOAS System (Water Source Heat Pump Fan Coils)

- HVAC 7: DOAS System (Active Chill Beams)

- HVAC 8: DOAS System (Passive Chill Beams)

\section{Retrofit Strategy package set up}

Based on the results from building envelope and building system retrofit techniques, six different packages are proposed according to the energy saving potential, carbon emission reduction potential, construction feasibility and initial cost (refer to table 1), simulated final site energy use intensity also provided.

Table 1 Building retrofit packages comparison to achieve near zero energy goal

\begin{tabular}{|c|c|c|c|c|c|c|c|c|c|}
\hline \multicolumn{7}{|c|}{ Building Envelope Techniques } & $\begin{array}{c}\text { HAV } \\
\text { C }\end{array}$ \\
\hline $\begin{array}{c}\text { Retrofi } \\
\text { t } \\
\text { packag } \\
\text { e }\end{array}$ & $\begin{array}{c}\text { T } \\
1\end{array}$ & 2 & 3 & 4 & 5 & 6 & 7 & 8 & \\
\hline P1 & & $\mathrm{x}$ & $\mathrm{x}$ & $\mathrm{x}$ & & $\mathrm{x}$ & & & $\begin{array}{c}\text { HVA } \\
\text { C 2 }\end{array}$ \\
\hline P2 & $\mathrm{x}$ & $\mathrm{x}$ & $\mathrm{x}$ & $\mathrm{x}$ & & $\mathrm{x}$ & & & $\begin{array}{c}\text { HVA } \\
\text { C 2 }\end{array}$ \\
\hline P3 & $\mathrm{x}$ & & & $\mathrm{x}$ & $\mathrm{x}$ & $\mathrm{x}$ & $\mathrm{x}$ & & $\begin{array}{c}\text { HVA } \\
\text { C 2 }\end{array}$ \\
\hline P4 & $\mathrm{x}$ & $\mathrm{x}$ & $\mathrm{x}$ & $\mathrm{x}$ & $\mathrm{x}$ & $\mathrm{x}$ & & & $\begin{array}{c}\text { HVA } \\
\text { C 2 }\end{array}$ \\
\hline P5 & $\mathrm{x}$ & $\mathrm{x}$ & $\mathrm{x}$ & $\mathrm{x}$ & $\mathrm{x}$ & $\mathrm{x}$ & $\mathrm{x}$ & & $\begin{array}{c}\text { HVA } \\
\text { C 2 }\end{array}$ \\
\hline P6 & & $\mathrm{x}$ & & $\mathrm{x}$ & & $\mathrm{x}$ & & & $\begin{array}{c}\text { HVA } \\
\text { C 2 }\end{array}$ \\
\hline P7 & & & $\mathrm{x}$ & $\mathrm{x}$ & & $\mathrm{x}$ & $\mathrm{x}$ & & $\begin{array}{c}\text { HVA } \\
\text { C 5 }\end{array}$ \\
\hline P8 & $\mathrm{x}$ & $\mathrm{x}$ & $\mathrm{x}$ & $\mathrm{x}$ & $\mathrm{x}$ & $\mathrm{x}$ & $\mathrm{x}$ & $\mathrm{x}$ & $\begin{array}{c}\text { HVA } \\
\text { C 8 }\end{array}$ \\
\hline
\end{tabular}

\section{Findings}

Based on field measurement (FM) results, several problematic areas are identified: (1) the acoustic quality is the biggest problematic area. The preferable noise level for open-plan class is $30 \mathrm{dBA}, 44-48 \mathrm{dBA}$ for closed office. $67 \%$ rooms on the ground floor has a noise level above $55 \mathrm{dBA}$, and total $40 \%$ rooms in the building has a noise level above the recommended level. (2) the secondary problematic area is thermal comfort, particular temperature. $30 \%$ of spaces have temperature outside of acceptable range based on ASHRAE 90.1 . $\left(20^{\circ} \mathrm{C}\right.$ to 23.6 ${ }^{\circ} \mathrm{C}$ ), and those spaces are overheated in both winter, spring and summer time. None of the space has a humidity that is outside of recommended range. (3) the third problematic area is the lighting level across the building has a very uneven distribution. less than $8 \%$ rooms are 
below the recommended light level range between 300500 lux. $18 \%$ rooms are overlit with a median lux level of 500 lux (refer to figure 4).

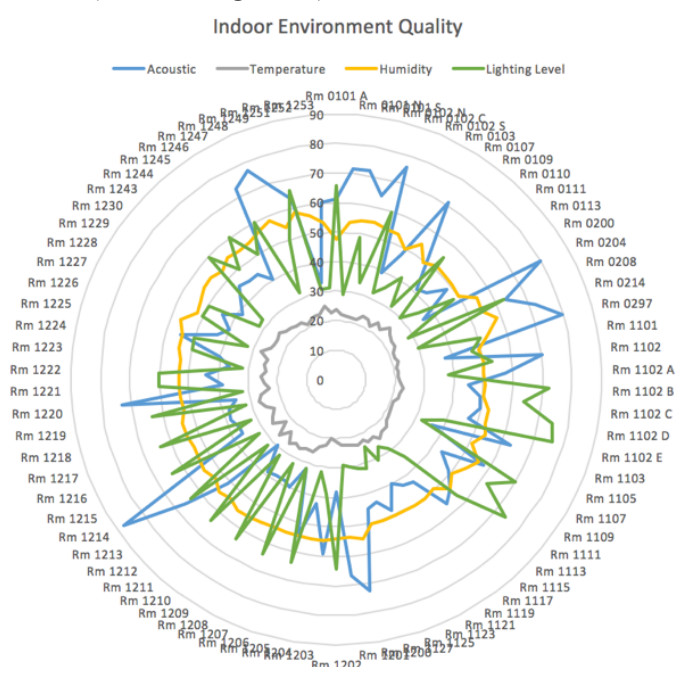

Figure 4 Field measurement results

The POS results shows people are least satisfied with speech privacy, thermal comfort, window view, and they are most satisfied with cleanliness and maintenance, amount of light, air quality and visual comfort. 55\% occupant dissatisfy with the speech privacy in their workspace, $38 \%$ occupant dissatisfy with the access to a window view, $37 \%$ occupant dissatisfy with the thermal comfort (refer to figure 5).

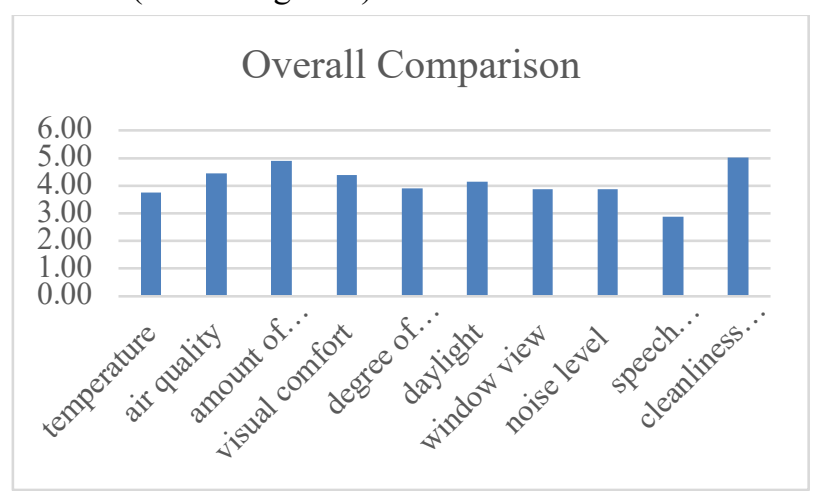

Figure 5 POS survey results

In general, POS results shows high-level alignment with FM data. Acoustic quality improvement and overheating mitigation are identified as top two primary focuses in order to improve indoor environment quality and users' satisfactions. There are areas that shows large discrepancies between POS and FM (refer to figure 6): air quality, window view and visual comfort. As FM shows the air quality and window view being sufficiently meeting the design criteria, lots of user expressed their dissatisfaction through survey, further in-depth individual interview could help to identify the causes of discrepancies.

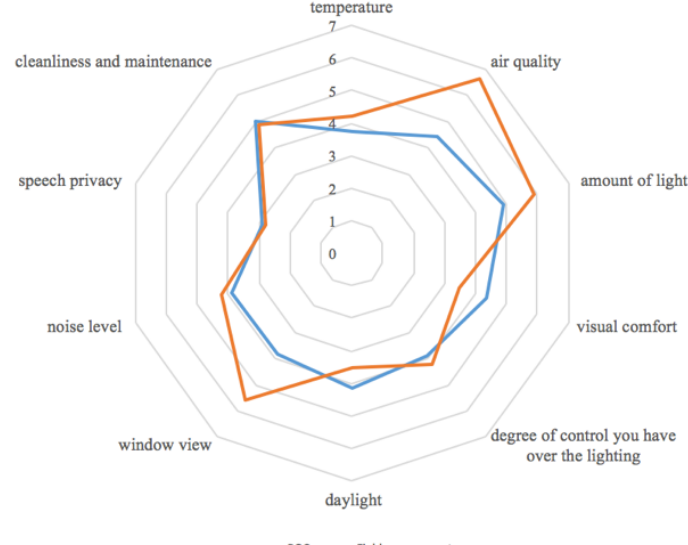

Figure 6 Problematic areas in existing building

\section{Building energy saving from retrofit packages}

Among eight different packages, P4 and P5 produce larges energy saving benefit with relative high initial construction cost. P1 and P6 produce very good energy saving benefit with relative low cost. $\mathrm{P} 2$ and $\mathrm{P} 3$ produce same result as $\mathrm{P} 1$ and $\mathrm{P} 6$, but with moderate initial cost. Lastly, P7 and P8 produce less energy and cost saving compared to the rest package (refer to figure 7).

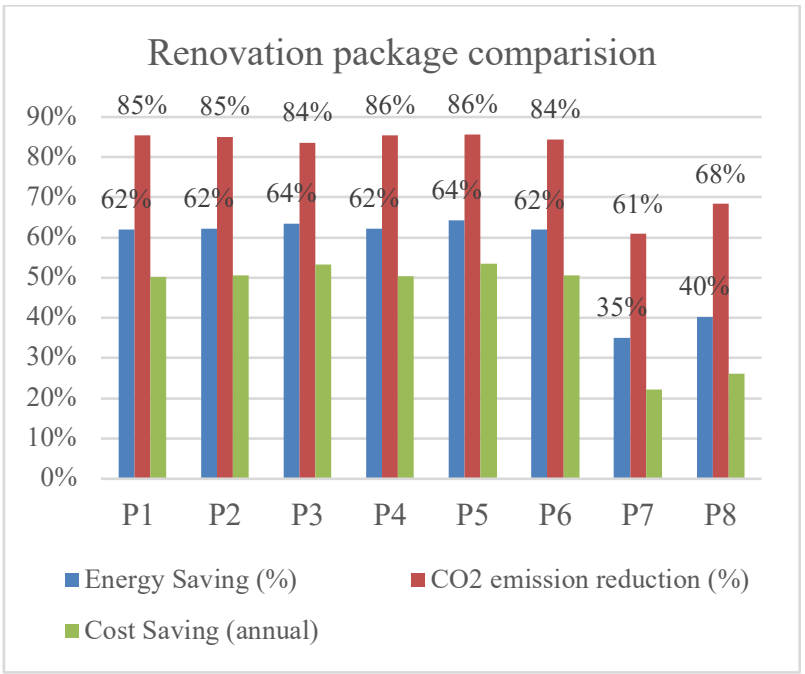

Figure 7 Renovation package energy, CO2 emission

reduction and cost saving comparison

\section{Conclusion}

The paper presented a novel BIM-BPM-BEM framework tailored towards education building renovation. It aims at selecting suitable renovation strategies to take account all performance indicators: energy consumption reduction, $\mathrm{CO} 2$ reduction, environmental impact reduction and indoor quality improvement. Varity renovation techniques are identified and multiple retrofit packages are compiled with four primary goals: 1) optimize the energy demand deduction to contribute to UMD overall carbon neutrality goal; 2) improve acoustic quality inside of school; 3) mitigate overheating problems; 4) minimize the long-term environmental impact. More in detail, with reference to the existing building, methods for an 
integrated existing condition diagnosis have been applied, by cross-referencing the filed measurement data, construction document review and numerical studies. Firstly, the data derived from filed measurement was cross-referenced with post occupancy survey and infrared themography scan to create an accurate building profile and BIM model. Then, the BIM model was clearly defined in order to be translated to BPM stage for simulating the energy performance of different renovation packages. The environmental impact of eight proposed renovation packages then compared using in BEM stage. Finally, the BPM and BEM results, cost indicators are looked at together to determine the optimized renovation solution for the existing building. The data used for environmental impact analysis and energy simulation are derived directly from the BIM model to ensure the data interoperability.

The results from BPM analysis and BEM analysis show the energy and cost saving benefit does not always align with the environmental impact reduction potential. For instance, Renovation package 4 and 2 produced high energy reduction, $\mathrm{CO} 2$ reduction and cost saving among the proposed options, however, it also produced largest environmental impact potential in all five indicators studied. Awareness of the asymmetric benefits between energy saving and environment impact could encourage design teams and decision makers to look into balanced solution for building renovations. Energy, indoor environmental quality and long-term environmental impact should be integrated and used together as building performance evaluation matrix. This research fills the current gap between energy efficiency improvement and environmental impact mitigation.

Another important insight from this study is that the importance of interoperability of different software could facility the data translation and transformation. Advanced digital technologies and platform such as BIM(Autodesk Revit), BPM (Sefaira) and BEM(Tally) make it possible for decision maker to exam all performance indicators within the same framework, therefore to make decision with a holistic understanding of all pros and cons of propose renovation strategies.

\section{References}

USEIA (US Energy Information Administration). (2015). A look at the US commercial building stock: Results from EIA's 2012 commercial buildings energy consumption survey (CBECS). Available online: https://www.eia.gov/consumption/commercial/repor ts/2012/buildstock/ (accessed on 4 March 2018)

Ascione, F., Bianco, N., De Masi, R. F., de’Rossi, F., \& Vanoli, G. P. (2015). Energy retrofit of an educational building in the ancient center of Benevento. Feasibility study of energy savings and respect of the historical value. Energy and Buildings, 95, 172-183.

De Angelis, E., Ciribini, A. L. C., Tagliabue, L. C., \& Paneroni, M. (2015). The Brescia Smart Campus Demonstrator. Renovation toward a zero energy classroom building. Procedia engineering, 118, 735743.

Niemelä, T., Kosonen, R., \& Jokisalo, J. (2016). Costoptimal energy performance renovation measures of educational buildings in cold climate. Applied energy, 183, 1005-1020.

Dalla Mora, T., Righi, A., Peron, F., \& Romagnoni, P. (2017). Cost-Optimal measures for renovation of existing school buildings towards nZEB. Energy Procedia, 140, 288-302.

Fonseca, P., Moura, P., Jorge, H., \& de Almeida, A. (2018). Sustainability in university campus: options for achieving nearly zero energy goals. International Journal of Sustainability in Higher Education, 19(4), 790-816.

Irulegi, O., Ruiz-Pardo, A., Serra, A., Salmerón, J. M., \& Vega, R. (2017). Retrofit strategies towards net zero energy educational buildings: a case study at the University of the Basque Country. Energy and Buildings, 144, 387-400.

Boarin, P.; Davoli, P. Deep renovation of the school building stock: The European opportunity and the Italian strategy/Riqualificazione profonda del patrimonio edilizio scolastico: L'opportunità offerta dall'Europa e la strategia adottata dall'italia. J. Technol. Archit. Environ. 2015, doi:10.13128/Techne-16110.

University of Maryland, Facility Management. Building Inventory. Available online: https://www.facilities.umd.edu/SitePages/FPBuilding Inventory.aspx (accessed on 7 June 2018).

Wikipedia. Building Information Modeling. Available online:https://en.wikipedia.org/wiki/Building inform ation_modeling (accessed on 28 May 2018).

Lu, W., Fung, A., Peng, Y., Liang, C., \& Rowlinson, S. (2014). Cost-benefit analysis of Building Information Modeling implementation in building projects through demystification of time-effort distribution curves. Building and environment, 82, 317-327.

Miller, C., Thomas, D., Irigoyen, S. D., Hersberger, C., Nagy, Z., Rossi, D., \& Schlueter, A. (2014). BIMextracted EnergyPlus model calibration for retrofit analysis of a historically listed building in Switzerland. Proceedings of SimBuild.

Zhao, H., Nagy, Z., Thomas, D., \& Schlueter, A. (2015). Service-oriented architecture for data exchange between a building information model and a building energy model. In Proceedings of International Conference CISBAT 2015 Future Buildings and Districts Sustainability from Nano to Urban Scale (No. CONF, pp. 761-766). LESO-PB, EPFL.

Ojczyk, C. (2014). Cost Analysis of Roof-Only Air Sealing and Insulation Strategies on 1 1/2-Story Homes in Cold Climates (No. DOE/GO-1020144552). NorthernSTAR, St. Paul, MN (United States). 
Shaw, C. Y., \& Jones, L. (1979). Air tightness and air infiltration of school buildings. National Research Council, Division of Building Research.
Sherman, M. H., \& Chan, W. R. (2006). Building air tightness: research and practice. In Building Ventilation (pp. 155-180). Routledge. 